Article

\title{
The Investigation of Organic Binder Effect on Morphological Structure of Ceramic Membrane Support
}

\author{
Mohamed Boussemghoune ${ }^{1,2}$, Mustapha Chikhi ${ }^{1}$, Yasin Ozay ${ }^{2}$, Pelin Guler ${ }^{3}$, \\ Bahar Ozbey Unal ${ }^{4}$ and Nadir Dizge ${ }^{2, *}$
}

1 Department of Environfmental Engineering, Salah Boubnider Constantine 3 University, Constantine 25000, Algeria; mohamed.boussemghoune@univ-constantine3.dz (M.B.);

mustapha.chikhi@univ-constantine3.dz (M.C.)

2 Department of Environmental Engineering, Mersin University, Mersin 33343, Turkey;

yasinozay@mersin.edu.tr

3 Department of Nanotechnology and Advanced Materials, Mersin University, Mersin 33343, Turkey; pelinguler@mersin.edu.tr

4 Department of Environmental Engineering, Gebze Technical University, Kocaeli 41440, Turkey; bozbey@gtu.edu.tr

* Correspondence: ndizge@mersin.edu.tr

Received: 24 March 2020; Accepted: 1 May 2020; Published: 6 May 2020 updates

\begin{abstract}
In this study, we investigated the effect of different organic binders on the morphologic structure of ceramic membrane support. Natural raw clay material (kaolin) was used as the main mineral for ceramic membrane support. The physical and chemical properties of kaolin powder and the supports were identified by X-ray fluorescence (XRF), X-ray diffraction (XRD), Fourier-transform infrared spectroscopy (FTIR), Brunauer-Emmett-Teller (BET), thermo gravimetric analysis (TGA), scanning electron microscopy (SEM), particle size and zeta potential distribution. Based on the XRF test, the main composition of kaolin powder was $\mathrm{SiO}_{2}(47.41 \%)$ and $\mathrm{Al}_{2} \mathrm{O}_{3}(38.91 \%)$, while the rest were impurities. The FTIR spectra showed the functional groups of Si-O and Al-O. The XRD diffractogram of natural raw clay powder identified kaolinite and nacrite were the main mineral phase whereas muscovite and quartz were detected in small quantities in the sample. After prepared the ceramic membrane supports, XRD diffractogram showed that anorthite and gehlenite were detected as the main mineral phases for ethylene glycol (EG), gelatin, methocel and for polyethylene glycol (PEG), respectively. According to BET analyses, the maximum and the minimum pore width were obtained for PEG and gelatin organic binders.
\end{abstract}

Keywords: organic binder; natural clay; kaolin; ceramic support; characterization

\section{Introduction}

Polymers and ceramics were the main materials that were used for the fabrication of the membranes. Polymeric membranes were preferred due to their low cost and flexible usages compared to ceramic membranes [1]. However, the usage area of ceramic membranes has been started to increase day by day due to their high porosity, high-temperature resistance, good corrosion resistance, high chemical stability, the possibility of regeneration and long lifespan [2-4].

Generally, ceramic membranes consist of at least one or more powders, such as kaolin, feldspar, natural corundum, quartz and binders and other additives. Recently, many authors have focused their research on the development of low cost ceramic membranes based on natural materials such as apatite powder, natural raw clay, graphite, phosphates, dolomite and kaolin $[5,6]$. Kaolin has a wide 
usage area to prepare ceramic membrane support or filtration layer due to its cheapness and the main components of the kaolin, which are $\mathrm{Al}_{2} \mathrm{O}_{3}$ and predominantly $\mathrm{SiO}_{2}[7,8]$.

Kaolin has an extensive uses and applications in the industry such as filler, extender, ceramic raw material and pigment. Moreover, it is a significant raw material to refractories and to catalyst, cement and fiberglass industries [9,10]. Alumina can also be produced by hydrochloric acid treatment of kaolin clays [11]. The increasing demand for aluminum worldwide increases the interest in marginal technologies to produce alumina from clays. The new technologies have been developed so far. For example, a method of alumina production based on hydrochloric acid processing of kaolin clays was developed and physico-chemical properties of alumina obtained by the hydrochloric acid technology were investigated [11]. The extraction of alumina from the kaolin was also obtained through the leaching process, using aqueous solutions of sodium carbonate as a leaching agent [12].

The major materials for ceramic membranes comprise alumina $\left(\mathrm{Al}_{2} \mathrm{O}_{3}\right)$, silicon oxide $\left(\mathrm{SiO}_{2}\right)$, zirconia $\left(\mathrm{ZrO}_{2}\right)$, titanium oxide $\left(\mathrm{TiO}_{2}\right)$, etc. [13]. Membrane morphology, mechanical strength and filtration performance of the ceramic membranes can be optimized by the addition of pore-forming materials, binders and other additives [14,15]. Although many reviews on selective membrane layers have been reported in the literature, there were not enough reviews on characterization of ceramic support $[16,17]$. Therefore, binders play important roles in the manufacturing of ceramic support and some of the reviews focused on the preparation of ceramic support with different binders $[16,18]$. Binders are used for the enhancement in the plasticity of the feed composition or improvement in the support layer of the ceramic membrane [16]. Optimization of the binder concentration and sintering temperature ensure the uniformity of the membrane morphology $[19,20]$. Organic binders like polyvinyl alcohol (PVA), polyethylene glycol (PEG), polyethylene oxide (PEO) and inorganic polymers such as sodium metasilicate and boric acid can be used as binders for the ceramic membrane support layer. Jana et al. investigated the effect of various inorganic binders such as sodium carbonate, sodium metasilicate and boric acid on ceramic membrane properties and they observed that the mechanical strength of the ceramic membrane increased by the addition of binding materials while the excess amounts of binding materials caused the ceramic membrane to stick on the furnace floor [21]. In addition, it has been reported that the addition of boric acid increased membrane strength more than sodium metasilicate [21]. Additionally, it was shown that binders have a significant effect on both membrane porosity, water resistance of the compounds and membrane strength [22]. In another study, the effect of binder addition was investigated on microstructure, mechanical behavior and electrical properties of $\mathrm{NiO}$-added $\mathrm{Pb}((\mathrm{Zn} 1 / 3 \mathrm{Nb} 2 / 3) 0.20(\mathrm{Zr} 0.50 \mathrm{Ti} 0.50) 0.80) \mathrm{O} 3$ ceramics. It was reported that the $\mathrm{NiO}$ addition weakened the dielectric relaxor behavior and improved the piezoelectric properties of the ceramics [23].

Generally, organic binders are made from polymers with more or less long chains where polar groups are present. Organic binders are also used in glazes and engobes to provide good adhesion to the ceramic surface, prevent sedimentation, as well as improve rheological properties. It is clear from the above literature that binders play especially important roles in ceramic membrane production. It is well known that membrane morphology is a key parameter in ceramic membrane production and binder plays an important role. Therefore, it is important to add binders and optimize binder content that affects membrane morphology [16]. We believe that organic binder types also are vital parameters for obtaining uniformity in the membrane texture, such as providing equal range of pores. Although there are many studies that investigated the effect of dominantly inorganic binders on membrane properties in the literature $[16,20,24,25]$, this is the first comprehensive study that examined the effect of different organic binders on the properties of the ceramic membrane support. In this study, we investigated the effect of four different organic binders (methocel, PEG, gelatin and ethylene glycol) on the ceramic membrane support morphology and characterization such as specific surface area, pore size distribution and chemical phases composition. Kaolin was used as a natural raw clay material which is predominantly located in Mersin province, south-east of Turkey. 


\section{Material and Methods}

\subsection{Natural Raw Clay (Kaolin) Material}

The natural raw clay material (kaolin) was kindly provided from NG Kütahya Ceramic, Kütahya, Turkey. NG Kütahya ceramics factory realizes Turkey's largest ceramics production. The production ranges from $10 \mathrm{~cm} \times 20 \mathrm{~cm}$ to $120 \mathrm{~cm} \times 240 \mathrm{~cm}$ dimensions, as floor-wall tiles, glazed porcelain and glass mosaics. The kaolin was sieved pass through a 325-mesh screen, then $<45 \mu \mathrm{m}$ kaolin powders were obtained and used for further experiments. Starch was purchased at a local market. Calcium carbonate, methocel, gelatin, polyethylene glycol (PEG) and ethylene glycol (EG) was purchased from Sigma-Aldrich. When the literature was researched, we noticed that these four organic binders were used extensively. For this reason, these organic binders were selected in this study. The chemical formula of organic materials used as a binder are given in Table 1.

Table 1. The chemical formula of organic materials.

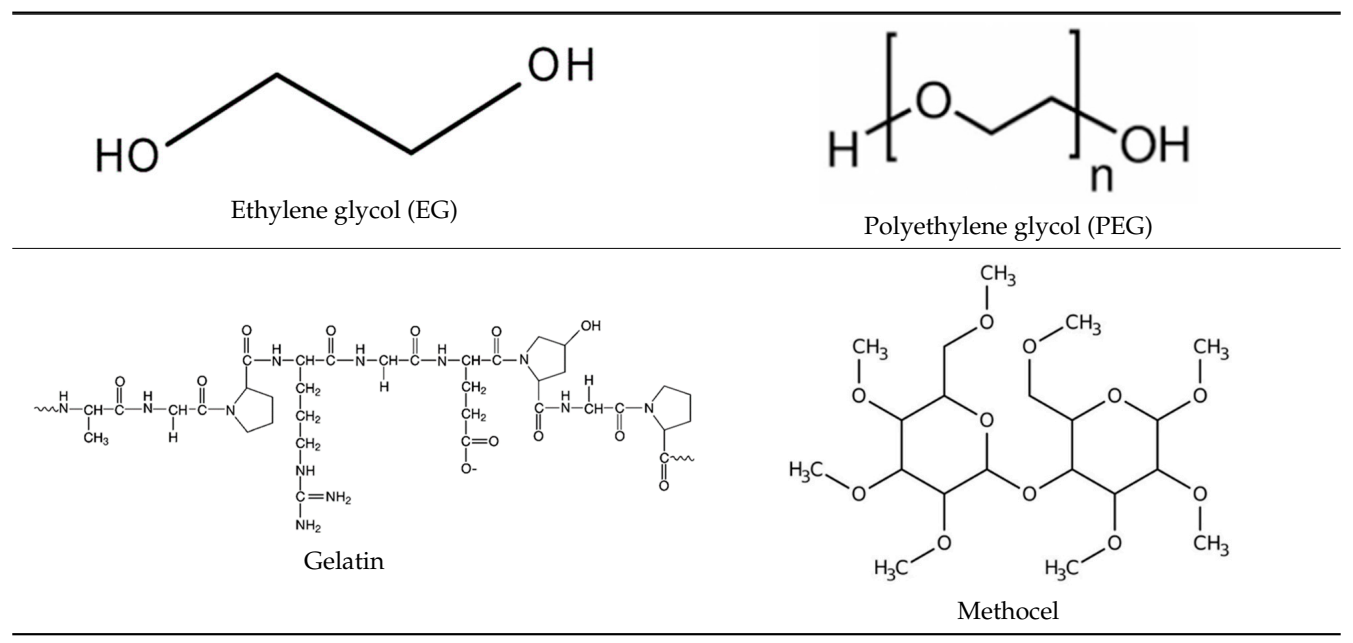

\subsection{Preparation of Mixture for Ceramic Membrane Supports}

In this work, we used two inorganic raw materials (kaolin and calcium carbonate), one organic plasticizer (starch) and four different organic binders (methocel, gelatin, polyethylene glycol and ethylene glycol) (Figure 1). After mixing the kaolin (70\%), calcium carbonate $(25 \%)$, starch $(2 \%)$ and organic binders (3\%), $3.5 \mathrm{~g}$ of powder mixture was weighed and poured into the press mold with a diameter of $4 \mathrm{~cm}$. Then, 6 tons of pressure was applied by manual hydraulic pressing (MSE Technology) to obtain circular ceramic membrane supports.

\subsection{Sintering Process of Ceramic Membrane Supports}

After the pressing step, pelleted samples were put into the sintering tables and were placed into the oven for sintering process. The samples were sintered at high temperature by using furnace (Protherm PLF 160/9) to improve the strength of the membrane supports. First, the temperature was increased $\left(250^{\circ} \mathrm{C}\right)$ at heating rate of $2^{\circ} \mathrm{C} / \mathrm{min}$. Second, the temperature was increased to $1200^{\circ} \mathrm{C}$ at heating rate of $5{ }^{\circ} \mathrm{C} / \mathrm{min}$. Finally, they were allowed to cool spontaneous up to room temperature. The sintering process are given in Figure 2.

\subsection{Characterization Methods}

X-ray Fluorescence (XRF) analysis of kaolin powder was used to determine the elemental composition of kaolin. The samples were loaded in the XRF instrument (Rigaku, ZSX Primus II) for elemental analysis. The instrument was operated at maximum voltage and current $60 \mathrm{kV}$ and $1 \mathrm{~mA}$, respectively, to generate the $\mathrm{X}$-rays. 
The mineralogical analysis of kaolin powder was characterized by X-ray Diffraction (XRD) (Bruker Smart Apex II Quazar). This technique identifies the crystalline phases present in our raw natural clay material. The measurement was made by a diffractometer having a $\mathrm{Cu}$ cathode of wavelength $\lambda=1.54 \AA$, equipped with a goniometer and X-ray detector was operated under the following conditions $(40 \mathrm{kV}, 40 \mathrm{~mA})$. The samples were subjected to X-ray diffraction in $2 \theta$ angles ranging from 5 to $80^{\circ}$ with a step size of 0.05 degrees and scanning rate $1^{\circ}$ per minute.

Brunauer-Emmett-Teller (BET) surface analysis is regarded to be an important characterization technique for ceramic membrane support to explain the physical adsorption of gas molecules on the solid surface and to measure of the specific surface area of membranes. The samples for surface area analysis were dried initially at $100{ }^{\circ} \mathrm{C}$ for $3 \mathrm{~h}$ prior outgassing and BET isotherm studies were performed in the relative pressure range of 0.1 to 1.0 (Micrometrics Surface Area and Porosity, TriStar II).

The particle size distribution was determined by a particle analyzer from Malvern Instruments (Malvern Zetasizer equipped with MPT-2 Titrator, Nano ZS), over a range of 0.01 to $3000 \mu \mathrm{m}$. The device makes it possible to obtain a distribution curve for the sizes of suspended particles.
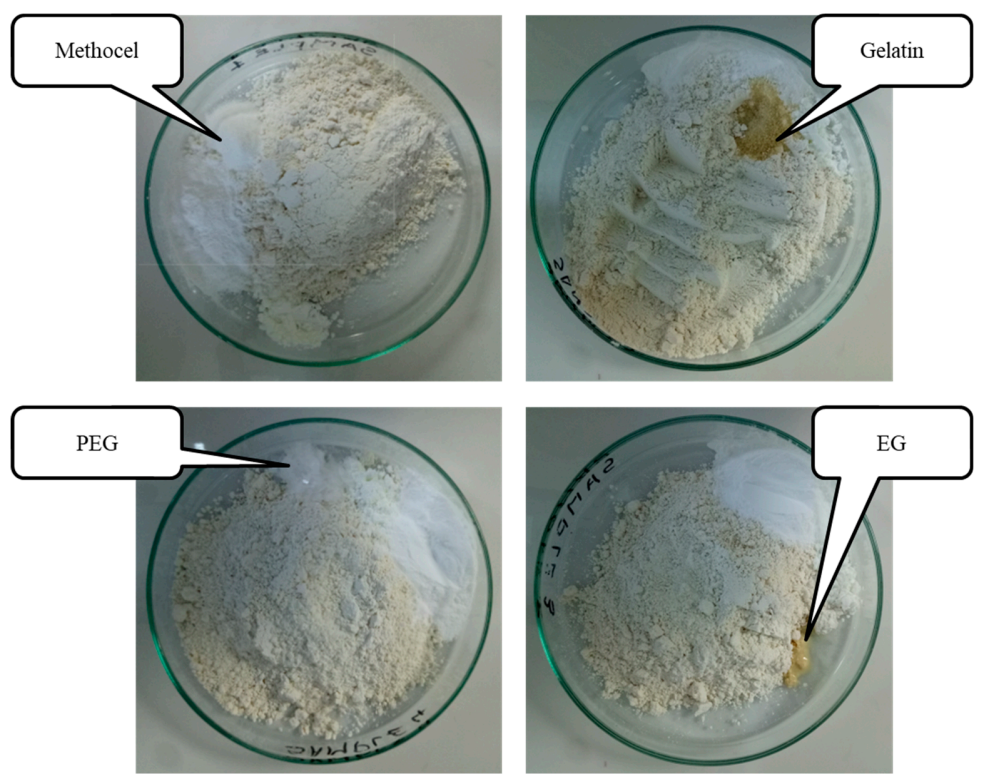

Figure 1. Different organic binders used in the mixture during the preparation of the ceramic membrane support.

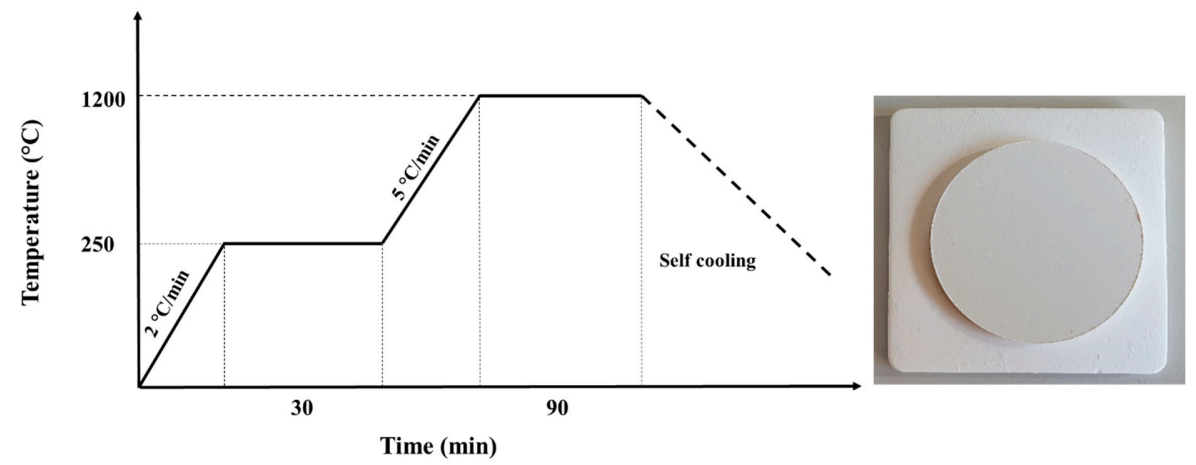

Figure 2. Sintering process of ceramic membrane supports.

The structural compositions of the ceramic membrane supports were studied by Fourier Transform Infra-Red (FTIR) Spectroscopy in the wave numbers ranging from $450-4000 \mathrm{~cm}^{-1}$ (Perkin Elmer).

All the membrane samples for SEM analysis (Zeiss, Supra 55) were washed three times with deionized water and dried for $10 \mathrm{~h}$ to remove the trace amount of solvent and moisture. The specific 
slot in specimen chamber was covered with carbon tape and membrane was simply attached onto it. Samples were coated with platinum by low vacuum sputter coating in order to increase the conductivity of the membranes and to obtain superior image quality.

Membrane samples were used for TGA analyses (Mettler Toledo) after pre-heating at $100^{\circ} \mathrm{C}$ to remove loosely bound moisture. Samples were subjected to maximum of $800{ }^{\circ} \mathrm{C}$, at gas flow rate of $45 \mathrm{~mL} / \mathrm{min}$ and a consistent temperature ramp of $5^{\circ} \mathrm{C} / \mathrm{min}$.

\section{Results and Discussion}

\subsection{Characterization of Kaolin Powder}

The composition of kaolin powders was analyzed using XRF and the results are shown in Table 2. The kaolin was mainly composed of $\mathrm{SiO}_{2}(47.41 \%)$ and $\mathrm{Al}_{2} \mathrm{O}_{3}(38.91 \%)$ minerals. However, there were still many impurities in the kaolin powders such as $\mathrm{Fe}_{2} \mathrm{O}_{3}, \mathrm{MgO}, \mathrm{K}_{2} \mathrm{O}, \mathrm{CaO}, \mathrm{Na}_{2} \mathrm{O}, \mathrm{P}_{2} \mathrm{O}_{5}, \mathrm{TiO}_{2}$.

Table 2. Chemical compositions of kaolin powders composition based on XRF analysis.

\begin{tabular}{ccc}
\hline Compound & Value & Unit \\
\hline Loss on ignition & 12.91 & $\%$ \\
$\mathrm{SiO}_{2}$ & 47.41 & $\%$ \\
$\mathrm{Al}_{2} \mathrm{O}_{3}$ & 38.91 & $\%$ \\
$\mathrm{~K}_{2} \mathrm{O}$ & 1.37 & $\%$ \\
$\mathrm{Fe}_{2} \mathrm{O}_{3}$ & 0.66 & $\%$ \\
$\mathrm{MgO}$ & 0.25 & $\%$ \\
$\mathrm{Na}_{2} \mathrm{O}$ & 0.10 & $\%$ \\
$\mathrm{CaO}$ & 0.05 & $\%$ \\
$\mathrm{TiO}_{2}$ & 0.05 & $\%$ \\
$\mathrm{P}_{2} \mathrm{O}_{5}$ & 0.02 & $\%$ \\
\hline
\end{tabular}

The composition of the kaolin powders was done by comparing the peak intensity position ( $2 \theta)$ in the sample X-ray diffraction contained in the Joint Committee for Powder Diffraction Standards (JCPDS). The peak intensity of the kaolin powders is shown in Figure 3. The powder consisted mainly of minerals associated with kaolinite, nacrite and other phases like muscovite and quartz. The intensities of this diffractogram showed that kaolinite and nacrite were the dominant phases where the peaks appear at $2 \theta\left(^{\circ}\right)=12.38^{\circ}, 24.94^{\circ}$ and $62.28^{\circ}$.

Figure 4 shows the particle size and zeta potential distribution of kaolin powder sieved pass through a 325-mesh screen. The particle size distribution was determined as $5.67 \pm 0.045 \mu \mathrm{m}$ using the Mastersizer 2000 software (Figure 4A). The zeta potential distribution was calculated as $-17.93 \pm 1.57 \mathrm{mV}$ (Figure 4B).

The infrared spectra of kaolin powders are represented in Figure 5 and the spectral positions are tabulated in Table 3.

Table 3. Comparative peak positions of infrared spectra (in $\mathrm{cm}^{-1}$ ) with possible assignments.

\begin{tabular}{|c|c|c|c|}
\hline Wavenumber $\left(\mathrm{cm}^{-1}\right)$ of Our Kaolin & Wavenumber $\left(\mathrm{cm}^{-1}\right)$ of Observed in Literature & Assignments & References \\
\hline 3685 & $3650-3695$ & vO-H, octahedral & [26] \\
\hline 3620 & $3598-3640$ & vO-H of hydration of water & [27] \\
\hline 1117 & 1108 & Si-O-Si & [28] \\
\hline 1010 & $1010-1022$ & strong $\mathrm{Si}-\mathrm{O}-\mathrm{Si}$ & [29] \\
\hline 745 & $621-884$ & $\mathrm{Al}-\mathrm{OH}$ & [30] \\
\hline
\end{tabular}




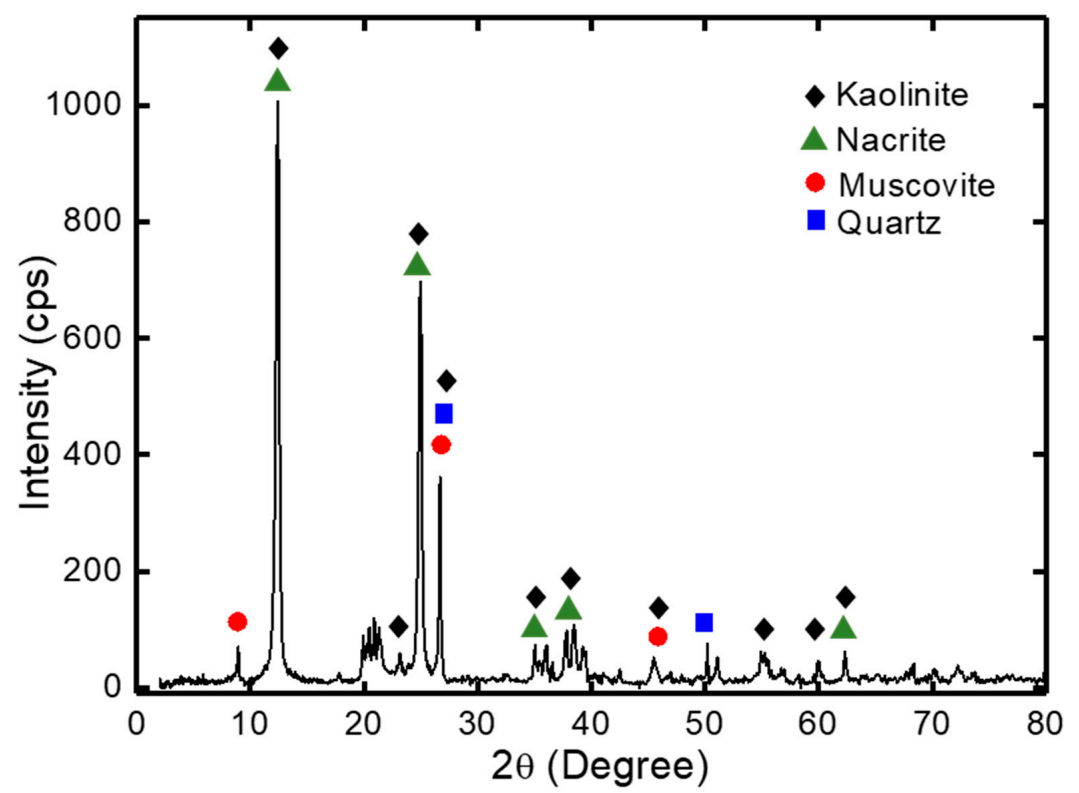

Figure 3. X-ray diffractogram of kaolin powders.
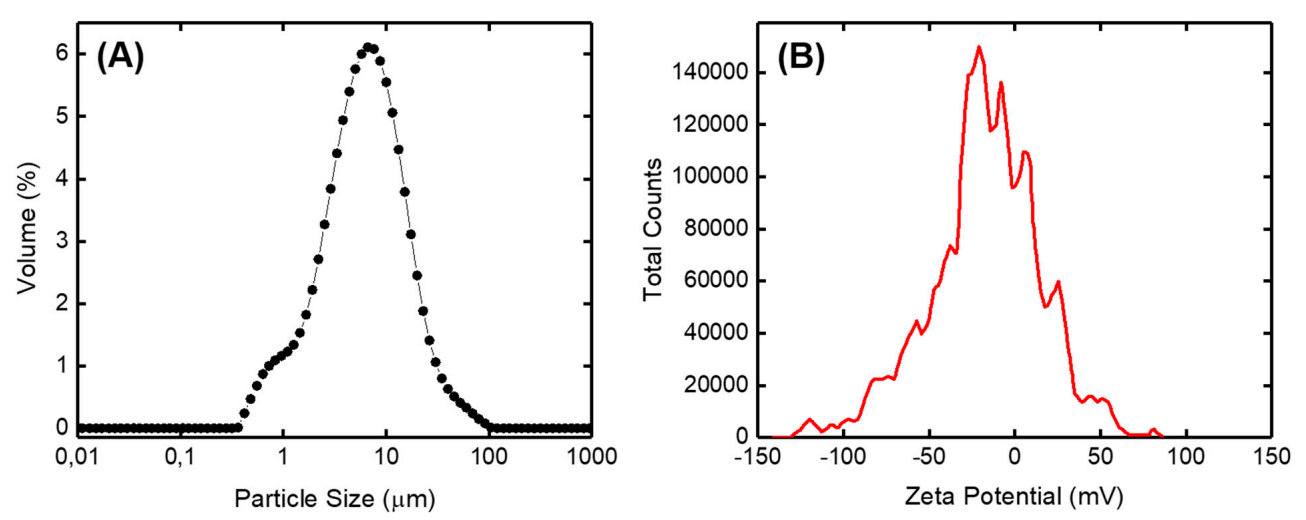

Figure 4. (A) Particle size distribution and (B) zeta potential distribution of kaolin powders.

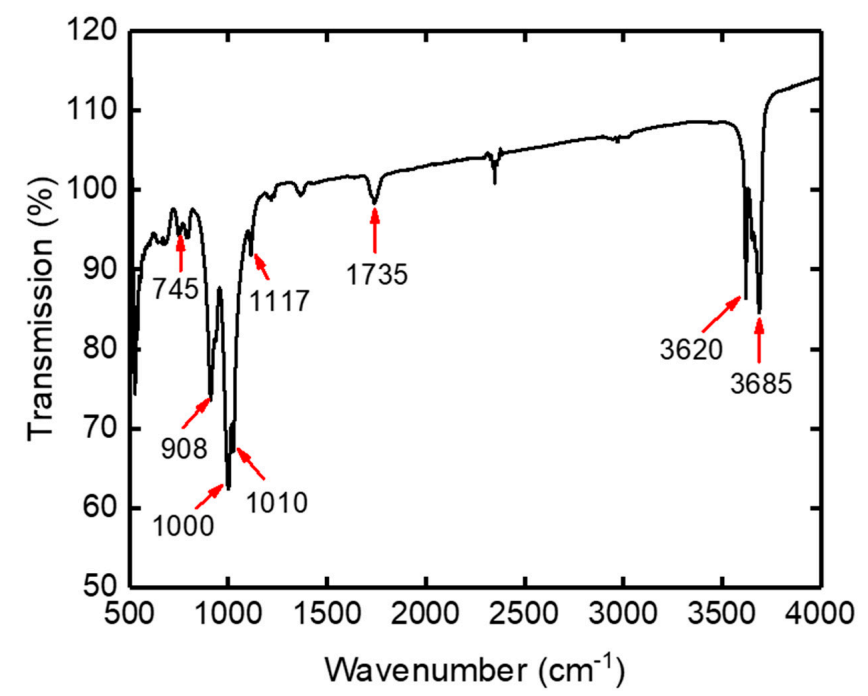

Figure 5. Fourier-transform infrared spectroscopy (FTIR) spectra of kaolin powders. 


\subsection{Characterization of Ceramic Membrane Supports}

The prepared ceramic membrane supports using four different organic binders were also characterized to investigate morphologic difference. Figure 6 shows the $\mathrm{X}$-ray diffractograms of ceramic membrane support prepared by using different organic binders. We noticed that some certain peaks detected in kaolin powders disappeared in the ceramic membrane support diffractograms after sintering at $1200{ }^{\circ} \mathrm{C}$. The kaolinite and nacrite minerals were transformed to other minerals with the presence of calcium carbonate by using the different organic binders. The absorption peaks of mineral quartz were appeared at $2 \theta=26.46^{\circ}, 26.72^{\circ}, 26.24^{\circ}$ and $26.57^{\circ}$ for EG, PEG, gelatin and methocel organic binders, respectively. Anorhite $\left(2 \theta=27.86^{\circ}\right)$ was detected when EG, gelatin and methocel were used as the organic binder. However, gismondine $\left(2 \theta=26.72^{\circ}\right)$, gehlenite $\left(2 \theta=31.56^{\circ}\right)$ and albite $\left(2 \theta=28.03^{\circ}\right)$ were detected for PEG and methocel organic binders, respectively (Figure 6). XRD results showed that organic binders affected ceramic membrane support structure.

Figure 7 shows the complete adsorption and desorption curves with the nitrogen adsorption-desorption isotherm at $423 \mathrm{~K}$ for $90 \mathrm{~min}$ for all ceramic membrane supports prepared with different organic binders. The specific surface areas obtained from the BET method were calculated as $7.432,10.403,10.625$ and $11.718 \mathrm{~m}^{2} / \mathrm{g}$ for gelatin, methocel, PEG and EG, respectively, which was valid within a relative pressure between 0.1-1.0. From the adsorption-desorption isotherm patterns, it could be interpreted that no hysteresis was observed and hence we could assume pores of the supports were cylindrical in shape.
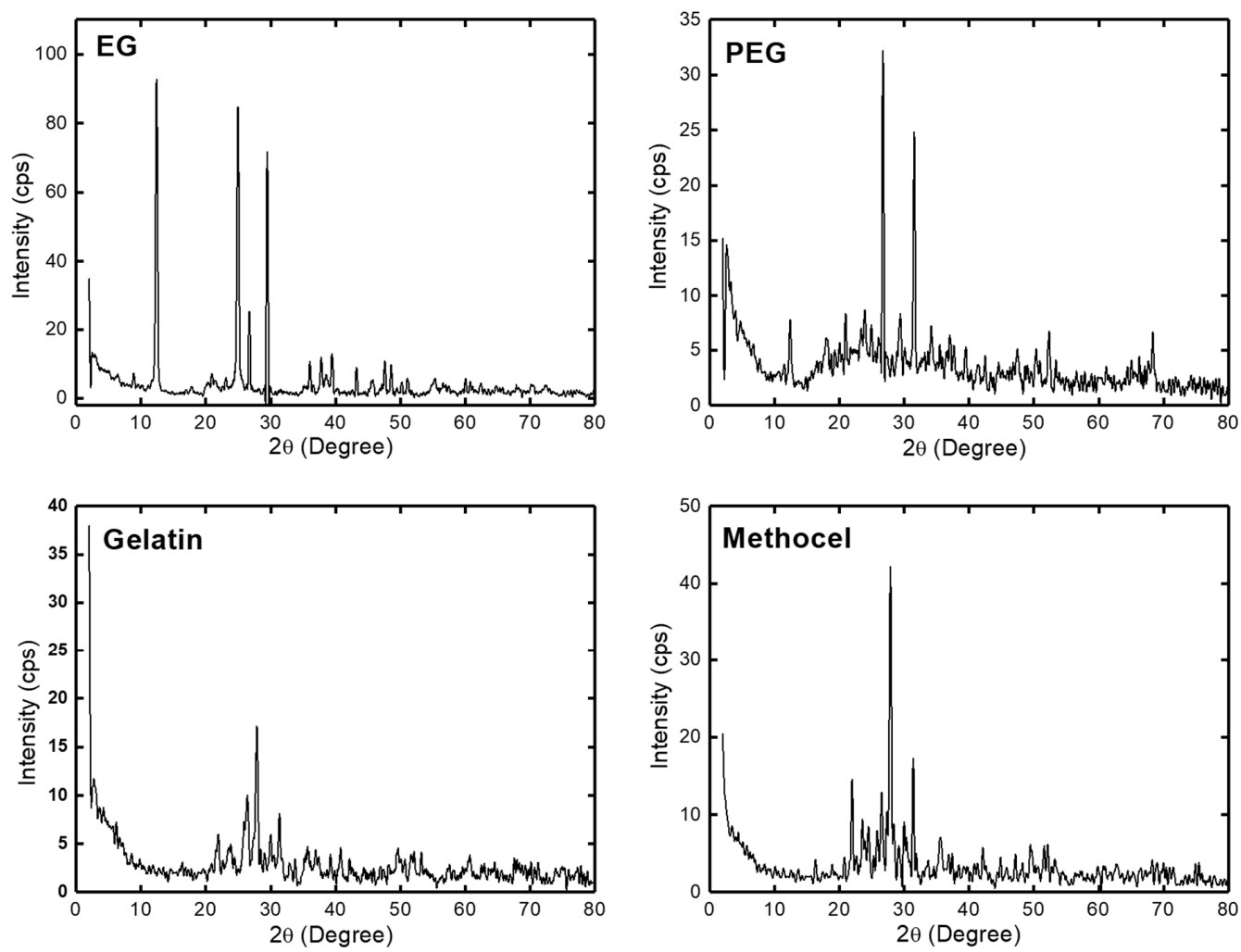

Figure 6. X-ray diffractogram of ceramic membrane supports prepared with different organic binders.

Pore size distribution was determined by gas adsorption techniques from the gas adsorption isotherm [31,32]. Table 4 shows the pore width distribution value of kaolin powder and ceramic membrane supports using the $\mathrm{BJH}$ method based on a discrete analysis of the desorption branch of the isotherm. The results showed that pore width of the ceramic membrane supports decreased after pressing and sintering. The maximum and the minimum pore width were obtained for PEG and gelatin organic binders. 


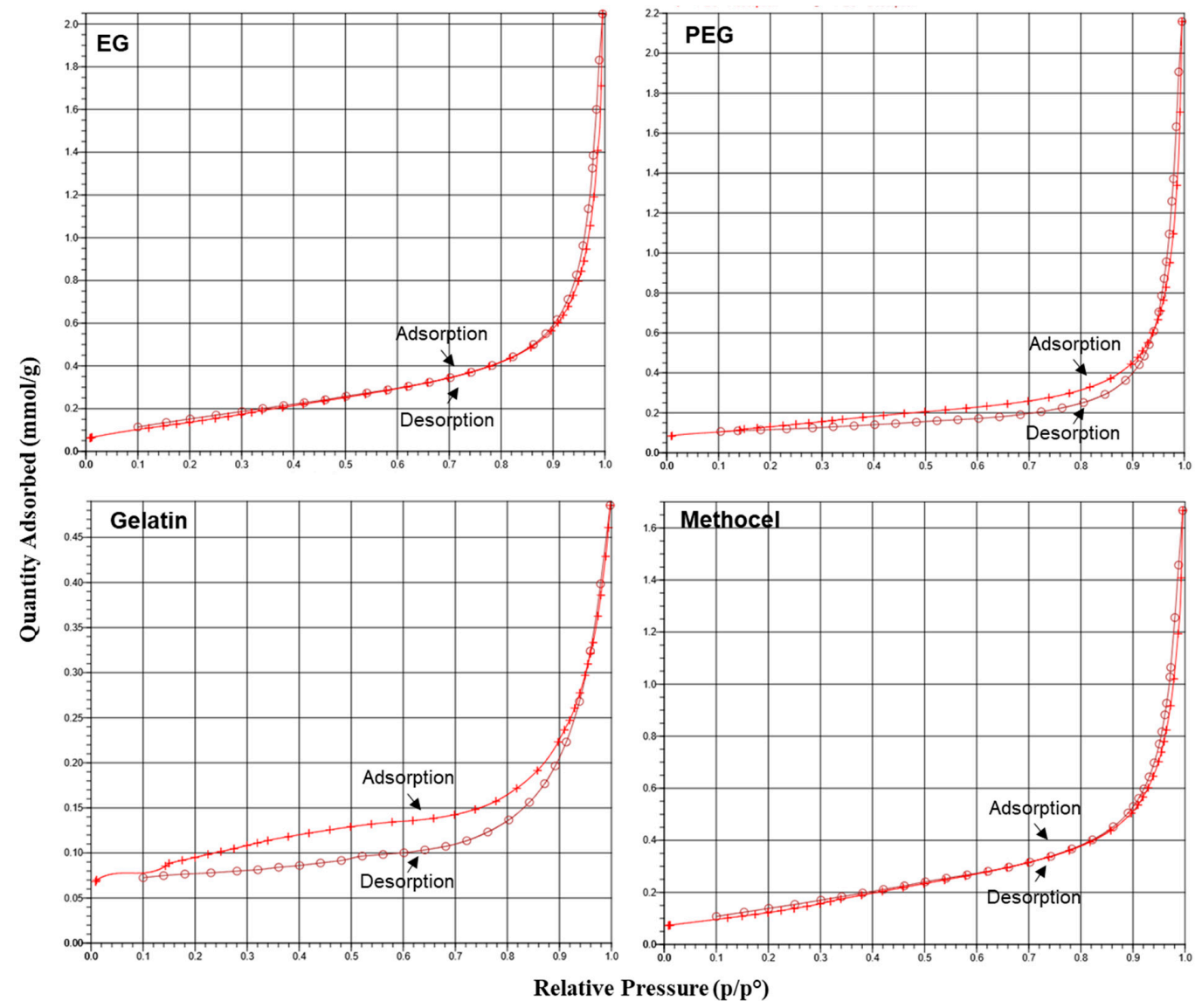

Figure 7. Adsorption-desorption isotherm of the ceramic membrane supports.

Table 4. Pore width distribution of kaolin powder and ceramic membrane supports.

\begin{tabular}{cc}
\hline Organic Binder Name & Pore Width $(\AA)$ \\
\hline EG & 149.340 \\
PEG & 204.899 \\
Gelatin & 103.608 \\
Methocel & 137.030 \\
Kaolin powder & 317.984 \\
\hline
\end{tabular}

In this study, optical microscope and SEM imaging techniques were used to characterize the defects generated by different organic binders. The images obtained from the optical microscope showed that certain particles with different dimensions did not bind and certain pores were formed after sintering of ceramic membrane supports when organic materials were used as a binder (Figure 8). We can say that the incorporation of methocel reduced the vacuum fractions in the ceramic membrane support compared to other organic binder.

The morphologic analysis of the ceramic membrane supports using SEM is presented in Figure 9. Some big holes were detected for gelatin organic binder. The distribution of gelatin in the mixture was difficult due to the larger size of its molecular weight and chain length. Therefore, its low homogeneous distribution may have caused large holes after combustion. Moreover, when considering at the structure of organic binders, methocel was nonpolar, EG and PEG were polar. EG and methocel can be considered as short chain binders which were adsorbed on the surface of kaolin particles easily than PEG and gelatin which were long chain binders. Therefore, water elimination may be easier during drying when non-polar and relatively short-chain methocel was used as the binder and it may create more homogeneous pore structure than others. However, it could be seen that the pores onto 
the support were uniform when methocel was used as the binder due to its strong deflocculating properties. Moreover, the pores were less connected to each other compared to EG and PEG binders.
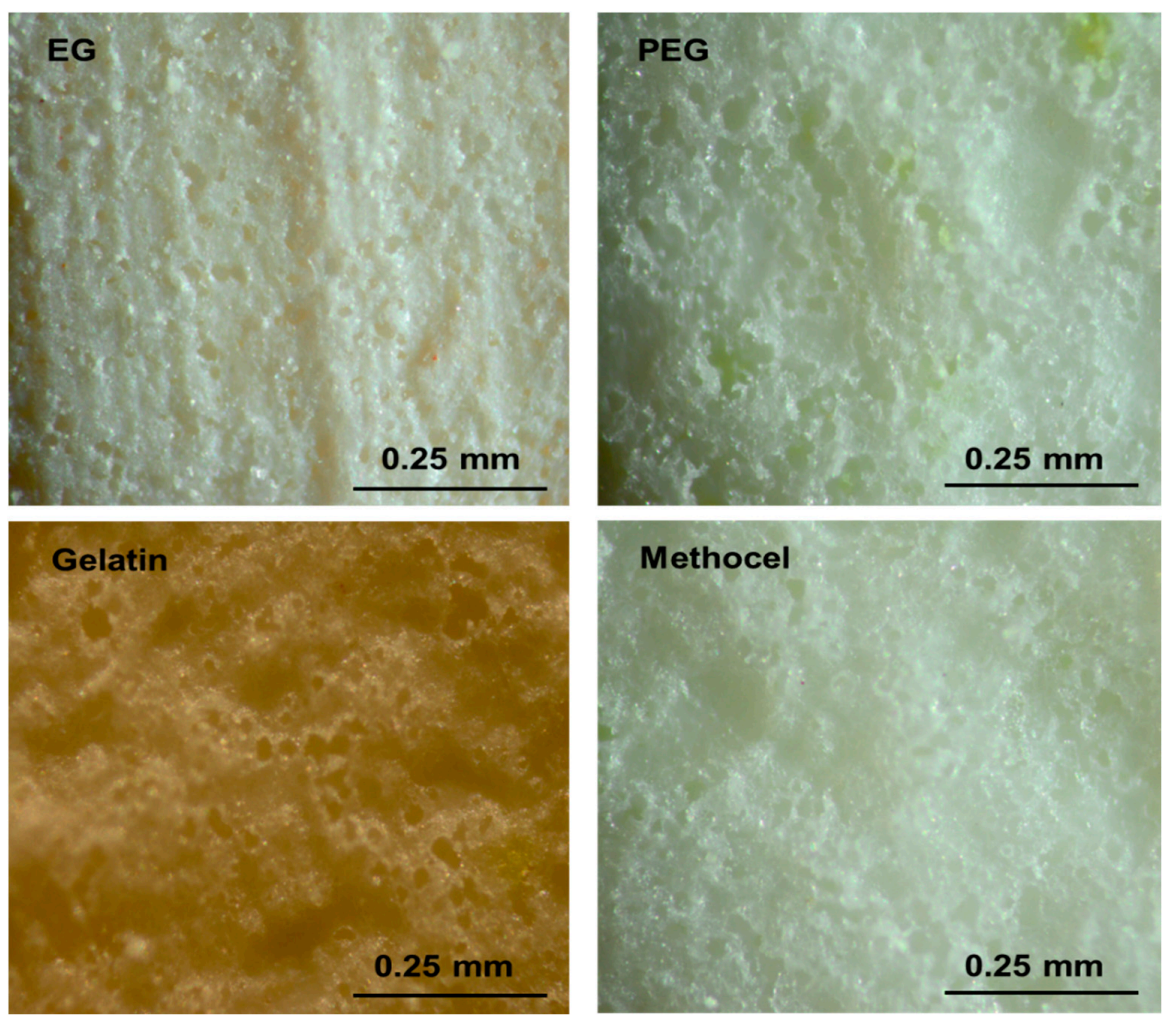

Figure 8. Optical microscope images of ceramic membrane support (magnification: 20×).
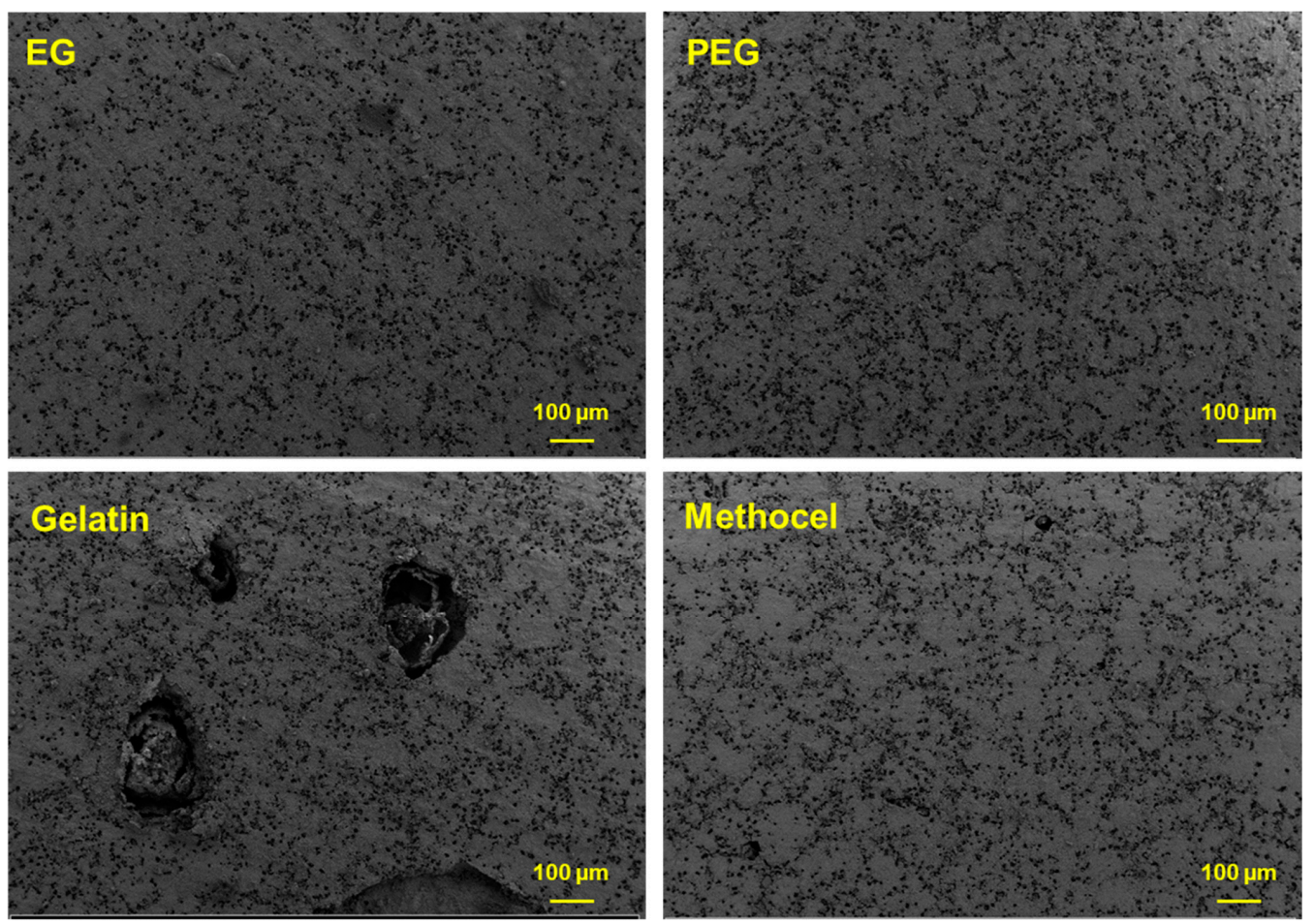

Figure 9. SEM images of ceramic membrane supports.

To understand all the physical and chemical transformations that occur in ceramic membrane support, thermal gravimetric analysis (TGA) proves to be the suitable technique. Figure 10 presents 
TGA of ceramic membrane supports prepared with different organic binders from room temperature to $700{ }^{\circ} \mathrm{C}$ at a heating rate of $10{ }^{\circ} \mathrm{C} / \mathrm{min}$. There were two weight losses corresponding to total weight of initial weight of samples (Figure 10). The first weight loss from 25 to $350^{\circ} \mathrm{C}$ was due to removal of adsorbed water and organic binders (EG, PEG, gelatin, methocel). The second weight loss from 350 to $550{ }^{\circ} \mathrm{C}$ corresponds to the dehydroxylation of structural hydroxyl groups due to the transformation of kaolinite into metakaolinite. TGA results showed that the most mass loss was observed for the gelatin.
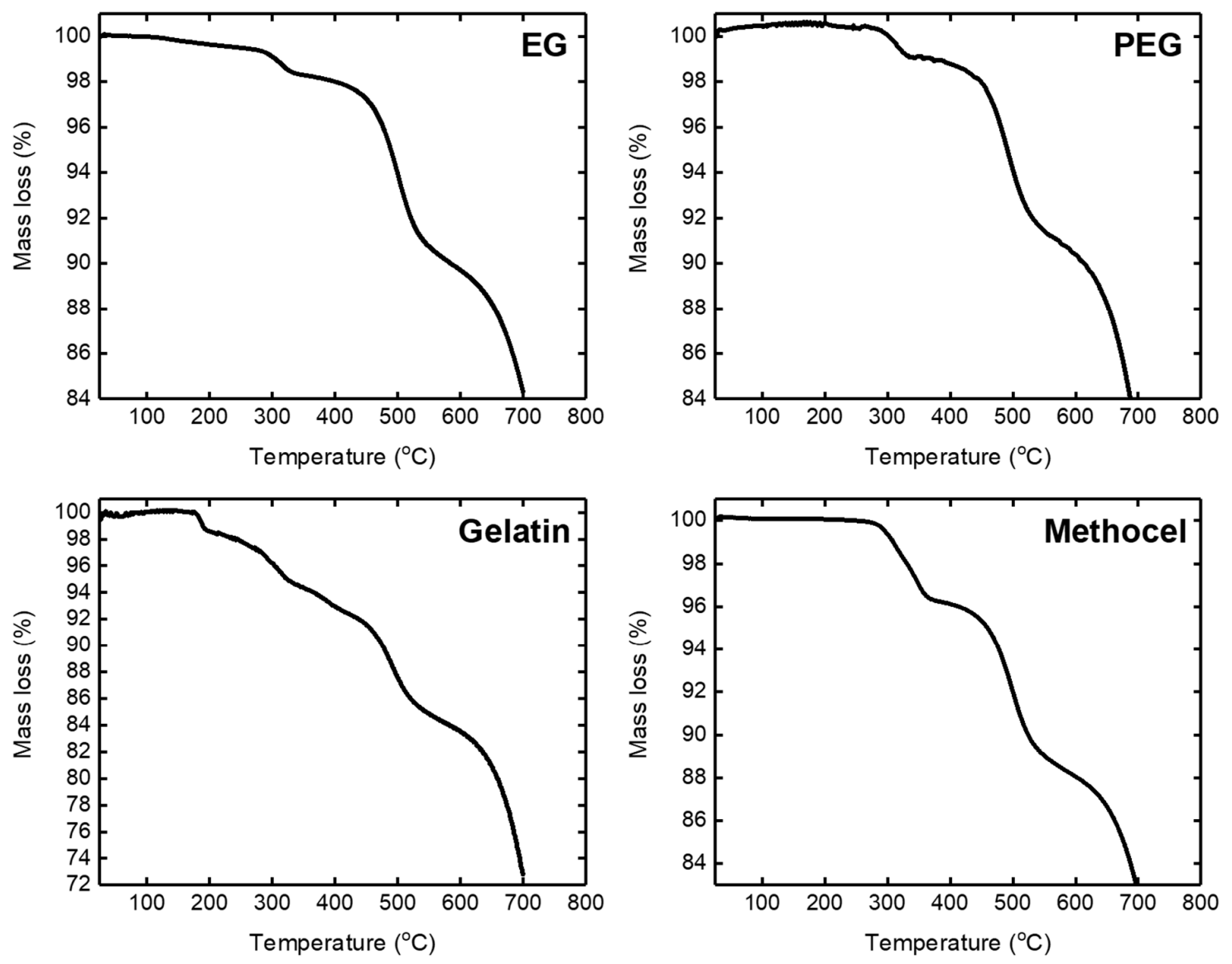

Figure 10. TGA of ceramic membrane supports.

\section{Conclusions}

In the pressing process of powders, adding organic binders makes possible a forming method that was independent of the plasticity. The natural raw clay material (kaolin) was used preferentially because of its specific properties and low cost for preparation of ceramic membrane support. The effect of different organic binders on morphologic structure of ceramic membrane support was investigated. $X R D$ results showed that organic binders affected ceramic membrane support structure. TGA results showed that the most mass loss was observed for the gelatin. SEM results also showed that gelatin generated defects in ceramic membrane support when used as the organic binder. Among the binders, methocel was supplied the best uniformity of pores. According to the analyses, it can be concluded that the chemical structure and properties such as length of polymer chain, molecular weight, polarity, viscosity, etc. of the organic binders have a significant effect on the ceramic membrane support structure.

Author Contributions: This present work was carried out by the contribution of all the authors cited in this article. N.D. and M.C. conceived the original idea. M.B. carried out the experimental preparation of ceramic membrane supports. Moreover, N.D. encouraged Y.O. and P.G. to investigate the morphologic structure of ceramic membrane support. X-ray diffraction and FTIR analyzes were also performed by B.O.U., who wrote the results of this section in the article. N.D. and M.C. conceived of the presented idea and planned the experiments. M.B., Y.O. and P.G. contributed to ceramic membrane supports preparation. N.D. took the lead in writing the manuscript. All authors 
provided critical feedback and helped shape the research, analyses and manuscript. All authors discussed the results and contributed to the final manuscript. All authors have read and agreed to the published version of the manuscript.

Funding: This research received no external funding.

Conflicts of Interest: The authors declare no conflicts of interest.

\section{References}

1. Hofs, B.; Ogier, J.; Vries, D.; Beerendonk, E.F.; Cornelissen, E.R. Comparison of ceramic and polymeric membrane permeability and fouling using surface water. Sep. Purif. Technol. 2011, 79, 365-374. [CrossRef]

2. Majouli, A.; Younssi, S.A.; Tahiri, S.; Albizane, A.; Loukili, H.; Belhaj, M. Characterization of flat membrane support elaborated from local Moroccan Perlite. Desalination 2011, 277, 61-66. [CrossRef]

3. Bouzerara, F.; Harabi, A.; Ghouil, B.; Medjemem, N.; Boudaira, B.; Condom, S. Elaboration and Properties of Zirconia Microfiltration Membranes. Procedia Eng. 2012, 33, 278-284. [CrossRef]

4. Malik, N.; Bulasara, V.K.; Basu, S. Preparation of novel porous ceramic microfiltration membranes from fly ash, kaolin and dolomite mixtures. Ceram. Int. 2020, 46, 6889-6898. [CrossRef]

5. Rekik, S.B.; Bouaziz, J.; Deratani, A.; Beklouti, S. Study of Ceramic Membrane from Naturally Occurring-Kaolin Clays for Microfiltration Applications. Period. Polytech. Chem. Eng. 2017, 61, 206. [CrossRef]

6. Kadiri, C.; Harabi, A.; Bouzerara, F.; Foughali, L.; Brihi, N.; Hallour, S.; Guechi, A.; Boudaira, B. Preparation and properties of tubular macroporous ceramic membrane supports based on natural quartz sand and dolomite. J. Aust. Ceram. Soc. 2019. [CrossRef]

7. Hou, Z.; Cui, B.; Liu, L.; Liu, Q. Effect of the different additives on the fabrication of porous kaolin-based mullite ceramics. Ceram. Int. 2016, 42, 17254-17258. [CrossRef]

8. Abdullayev, A.; Bekheet, M.; Hanaor, D.; Gurlo, A. Materials and Applications for Low-Cost Ceramic Membranes. Membranes 2019, 9, 105. [CrossRef]

9. Forano, C.; Hibino, T.; Leroux, F.; Taviot-Guého, C. Layered Double Hydroxides. In Developments in Clay Science; Elsevier: Cambridge, MA, USA, 2006; pp. 1021-1095. ISBN 0080441831.

10. Murray, H.H. Kaolin Applications. In Applied Clay Mineralogy-Occurrences, Processing and Application of Kaolins, Bentonites, Palygorskite-Sepiolite, and Common Clays; Elsevier: Cambridge, MA, USA, 2006; pp. 85-109. ISBN 9780444517012.

11. Pak, V.I.; Kirov, S.S.; Nalivaiko, A.Y.; Ozherelkov, D.Y.; Gromov, A.A. Obtaining alumina from kaolin clay via aluminum chloride. Materials 2019, 12, 3938. [CrossRef]

12. ElDeeb, A.B.; Brichkin, V.N.; Kurtenkov, R.V.; Bormotov, I.S. Extraction of alumina from kaolin by a combination of pyro- and hydro-metallurgical processes. Appl. Clay Sci. 2019, 172, 146-154. [CrossRef]

13. Xing, W.-H. Ceramic Membranes. In Membrane-Based Separations in Metallurgy; Elsevier: Cambridge, MA, USA, 2017; pp. 357-370. ISBN 9780128034279.

14. Mestre, S.; Gozalbo, A.; Lorente-Ayza, M.M.; Sánchez, E. Low-cost ceramic membranes: A research opportunity for industrial application. J. Eur. Ceram. Soc. 2019, 39, 3392-3407. [CrossRef]

15. Sondhi, R.; Bhave, R.; Jung, G. Applications and benefits of ceramic membranes. Membr. Technol. 2003, 2003, 5-8. [CrossRef]

16. Bose, S.; Das, C. Role of Binder and Preparation Pressure in Tubular Ceramic Membrane Processing: Design and Optimization Study Using Response Surface Methodology (RSM). Ind. Eng. Chem. Res. 2014, 53, 12319-12329. [CrossRef]

17. Hu, Z.; Yang, Y.; Chang, Q.; Liu, F.; Wang, Y.; Rao, J. Preparation of a High-Performance Porous Ceramic Membrane by a Two-Step Coating Method and One-Step Sintering. Appl. Sci. 2018, 9, 52. [CrossRef]

18. Hubadillah, S.K.; Harun, Z.; Othman, M.H.D.; Ismail, A.F.; Salleh, W.N.W.; Basri, H.; Yunos, M.Z.; Gani, P. Preparation and characterization of low cost porous ceramic membrane support from kaolin using phase inversion/sintering technique for gas separation: Effect of kaolin content and non-solvent coagulant bath. Chem. Eng. Res. Des. 2016, 112, 24-35. [CrossRef]

19. Kayvani Fard, A.; McKay, G.; Buekenhoudt, A.; Al Sulaiti, H.; Motmans, F.; Khraisheh, M.; Atieh, M. Inorganic Membranes: Preparation and Application for Water Treatment and Desalination. Materials 2018, 11, 74. [CrossRef] 
20. Das, N.; Maiti, H.S. Formatation of pore structure in tape-cast alumina membranes-Effects of binder content and firing temperature. J. Memb. Sci. 1998, 140, 205-212. [CrossRef]

21. Jana, S.; Purkait, M.K.; Mohanty, K. Preparation and Characterizations of Ceramic Microfiltration Membrane: Effect of Inorganic Precursors on Membrane Morphology. Sep. Sci. Technol. 2010, 46, 33-45. [CrossRef]

22. Ivanets, A.; Agabekov, V. Preparation and Characterization of Microfiltration Ceramic Membranes Based on Natural Quartz Sand. ChemJMold 2017, 12, 67-73. [CrossRef]

23. Zheng, M.-P.; Hou, Y.-D.; Ge, H.-Y.; Zhu, M.-K.; Yan, H. Effect of NiO additive on microstructure, mechanical behavior and electrical properties of 0.2PZN-0.8PZT ceramics. J. Eur. Ceram. Soc. 2013, 33, 1447-1456. [CrossRef]

24. Goh, P.S.; Ismail, A.F. A review on inorganic membranes for desalination and wastewater treatment. Desalination 2018, 434, 60-80. [CrossRef]

25. Buekenhoudt, A. Stability of Porous Ceramic Membranes. In Membrane Science and Technology; Elsevier: Cambridge, MA, USA, 2008; pp. 1-31. ISBN 9780444530707.

26. Dewi, R.; Agusnar, H.; Alfian, Z. Tamrin Characterization of technical kaolin using XRF, SEM, XRD, FTIR and its potentials as industrial raw materials. J. Phys. Conf. Ser. 2018, 1116, 042010. [CrossRef]

27. Hosseini, S.A.; Niaei, A.; Salari, D. Production of $\gamma-\mathrm{Al}_{2} \mathrm{O}_{3}$ from Kaolin. Open J. Phys. Chem. 2011, 1, $23-27$. [CrossRef]

28. Teresa, O.; Choi, C.K. Comparison between SiOC Thin Film by plasma enhance chemical vapor deposition and $\mathrm{SiO}_{2}$ Thin Film by Fourier Transform Infrared Spectroscopy. J. Korean Phys. Soc. 2010, 56, 1150-1155.

29. Irawati, U.; Sunardi, S.; Suraida, S. SINTESIS DAN KARAKTERISASI GAMMA ALUMINA $(\gamma-A 12 O 3)$ DARI KAOLIN ASAL TATAKAN, SELATAN BERDASARKAN VARIASI TEMPERATUR KALSINASI. Molekul 2013, 8, 31. [CrossRef]

30. Liu, C.; Shih, K.; Gao, Y.; Li, F.; Wei, L. Dechlorinating transformation of propachlor through nucleophilic substitution by dithionite on the surface of alumina. J. Soils Sediments 2012, 12, 724-733. [CrossRef]

31. Qabaqous, O.; Tijani, N.; Naciri Bennani, M.; El Krouk, A. Preparation and characterization of supports plans from the (Rhassoul) clay for mineral membranes. J. Mater. Environ. Sci. 2014, 5, 2244-2249.

32. Benito, J.M.; Conesa, A.; Rubio, F.; Rodríguez, M.A. Preparation and characterization of tubular ceramic membranes for treatment of oil emulsions. J. Eur. Ceram. Soc. 2005, 25, 1895-1903. [CrossRef] 